\title{
Pengaruh kompensasi finansial dan pemberdayaan terhadap kinerja karyawan
}

\author{
Irfandi $^{1}$, Yonathan Pongtuluran ${ }^{2}$, Dirga Lestari $\mathrm{AS}^{\mathbf{3}}$ \\ Fakultas Ekonomi dan Bisnis, Universitas Mulawarman \\ ${ }^{1}$ Email: irfandipang26@gmail.com \\ ${ }^{2}$ Email: yonathan.pongtuluran@feb.unmul.ac.id \\ ${ }^{3}$ Email: dirga.lestari.as@feb.unmul.ac.id
}

\begin{abstract}
Abstrak
Tujuan penelitian ini adalah untuk mengetahui pengaruh Kompensasi Finansial dan Pemberdayaan Terhadap Kinerja Karyawan PT. Samudra Maju Perkasa Kota Samarinda. Pengumpulan data peneliti menggunakan metode sampling jenuh. Jumlah Populasi adalah 38 Orang. Yang mana semuanya menjadi responden dalam penelitian ini. Penelitian ini menggunakan data primer yang diperoleh dengan penyebaran kuesioner kepada karyawan yang bekerja pada PT. Samudra Maju Perkasa Kota Samarinda. Hasil penelitian menunjukkan bahwa terdapat pengaruh positif dan signifikan kompensasi finansial terhadap Kinerja Karyawa PT. Samudra Maju Perkasa Kota Samarinda. Dan terdapat pengaruh positif dan signifikan Pemberdayaan terhadap Kinerja Karyawan PT. Samudra Maju Perkasa Kota Samarinda.
\end{abstract}

Kata Kunci: Kompensasi finansial; pemberdayaan dan kinerja karyawan

\section{The influence of financial compensation and empowerment of employee performance}

\begin{abstract}
The purpose of this study is to determine the effect of Financial Compensation and Empowerment Employee Performance PT. Samudra Maju Perkasa Samarinda City. The data collected by researcher using saturated sampling method. Population is 38 people. Which are all respondents in this study. This study uses primary data that developed with the distribution of questionnaires to employees working at PT. Samudra Maju Perkasa Samarinda City. The result of the research shows that there is a positive and significant influence to PT. Samudra Maju Perkasa Samarinda City. And there is a positive and significant influence Empowerment to Employee Performance PT. Samudra Maju Perkasa Samarinda City.
\end{abstract}

Keywords: Financial compensation, empowerment and employee performance 


\section{PENDAHULUAN}

Suatu perusahaan mengalami peningkatan atau mengalami kemajuan baik dari segi keuangan maupun kesejahteraan apabila didukung oleh komitmen dan loyalitas para karyawannya. Sebaliknya sumber daya manusia pula yang dapat menjadi penyebab terjadinya pemborosan dan ketidakefisienan dalam berbagai bentuknya. Karena itu memberikan perhatian dan penghargaan kepada karyawan merupakan salah satu tuntutan dalam keseluruhan upaya untuk mendapatkan kinerja yang baik.

Kinerja yang tinggi dapat dibentuk dengan adanya kesadaran setiap pimpinan perusahaan untuk memberikan dukungan kepada karyawan berupa keikutsertaan pemimpin dalam memberikan arahan mengenai pekerjaan yang dilakukan oleh setiap karyawan, dengan demikian karyawan dapat lebih memahami mengenai tanggung jawab pekerjaan yang mereka lakukan. Kinerja seseorang merupakan kombinasi dari kemampuan, usah, dan kesempatan yang dapat dinilai dari hasil kerjanya. Bisa dikatakan semakin baik kinerja karyawan diperusahaan tersebut maka semakin mudah perusahaan mencapai tujuannya, sebaliknya apabila kinerja karyawan itu rendah maka semakin sulit perusahaan mencapai tujuannya.

Dalam meningkatkan kinerja karyawan agar lebih baik dalam suatu perusahaan perlu dilakukan halhal yang bisa meningkatkan kinerja seorang karyawan, salah satunya adalah pemberian kompensasi yang adil dan layak bagi karyawan karena pada umumnya berpengaruh pada tingkap kepuasan, motivasi kerja, serta kinerja. Apabila perusahaan tidak mampu mengembangkan dan menerapkan suatu sistem kompensasi yang memuaskan, maka perusahaan akan kehilangan tenaga terampil dan berpengalaman serta akan kalah bersaing di pasaran tenaga kerja dan akhirnya dapat mencapai tujuan dan sasaran yang diinginkan.

Faktor lain yang dapat meningkatkan kinerja seorang karyawan adalah pemberdayaan karyawan. Pemberdayaan karyawan merupakan salah satu upaya untuk menciptakan lingkungan kerja yang aman dan nyaman sehingga karyawan bisa memberikan kontribusi yang optimal bagi perusahaan. Pemberdayaan karyawan yang dilakukan oleh perusahaan kepada karyawannya bisa memacu untuk meningkatkan kreatifitas, motivasi dan daya inovatif yang dimiliki oleh setiap karyawan dalam melaksanakan tugas dan tanggung jawabnya. Dengan adanya program pemberdayaan karyawan, kinerja karyawan akan meningkat. Sehingga tujuan perusahaan akan tercapai dengan baik, cepat dan fleksibel.

\section{Tinjauan Pustaka}

\section{Kompensasi Finansial}

Kompensasi merupakan kontra prestasi terhadap penggunaan tenaga atau jasa yang telah diberikan oleh tenaga kerja. Kompensasi merupakan jumlah paket yang ditawarkan organisasi kepada pekerja sebagai imbalan atas penggunaan tenaga kerjanya (Wibowo 2014:289).

\section{Pemberdayaan}

Menurut Stewart (2008) dalam Widodo (2015:200), “yang secara etomologis pemberdayaan berasal dari kata power berarti kekuasaan, yaitu kemampuan untuk mengusahakan agar sesuatu itu terjadi ataupun tidak sama sekali”.

Menurut Noe et. al. (2004) dalam Widodo (2015:202), "pemberdayaan merupakan pemberian tanggung jawab dan wewenang terhadap pekerjaan untuk mengambil keputusan menyangkut semua pengembangan produk dan pengambilan keputusan". Sedangkan Kahn (2007) dalam Widodo (2015:202), menjelaskan "pemberdayaan merupakan hubungan antara personel yang berkelanjutan untuk membangun kepercayaan antar karyawan dan manajemen".

\section{Kinerja Karyawan}

Secara etimologi, kinerja berasal dari kata prestasi kerja (performance). Sebagaimana dikemukakan oleh Mangkunegara (2015:67) bahwa istilah kinerja job performance atau actual performance (prestasi 
kerja atau prestasi sesungguhnya yang dicapai oleh seseorang) yaitu hasil kerja secara kualitas dan kuantitas yang dicapai oleh seorang pegawai dalam melaksanakan tugasnya sesuai dengan tanggung jawab yang diberikan padanya.

Coquitt, LePine, dan Wesson (2011:35) dalam Wibowo (2014:2), mengemukakan bahwa kinerja adalah nilai serangkaian perilaku pekerja yang memberikan kontribusi, baik secara positif maupun negative, pada penyelesaian tujuan organisasi.

\section{METODE}

Populasi untuk penelitian ini adalah seluruh karyawan yang ada pada PT. Samudra Maju Perkasa Kota Samarinda. Penelitian ini menggunakan sampel jenuh yaitu seluruh karyawan pada PT. Samudra Maju Perkasa yang berjumlah 38 orang menjadi responden. Data diperoleh melalui kuesioner dengan skala Likert 1-5. Data dianalisis dengan menggunakan paket program SPSS Versi 20.

\section{HASIL DAN PEMBAHASAN}

\section{Deskriptif Responden}

karakteristik responden berdasarkan pendidikan terakhir SMP sebesar 8\% atau sebanyak 3 orang. Untuk persentase pendidikan terakhir SMA/SMK sebesar $42 \%$ atau sebanyak 16 orang. Untuk persentase pendidikan terakhir D3 sebesar 24\% atau sebanyak 9 orang. Untuk persentase pendidikan terakhir S1 sebesar $26 \%$ atau sebanyak 10 orang.

karakteristik responden berdasarkan jenis kelamindengan jumlah responden laki-laki sebesar 68\% atau sebanyak 26 orang dan jumlah responden perempuan sebesar 32\% atau sebanyak 12 orang.

karakteristik responden berdasarkan usia 21-30 tahun sebesar 63\% atau sebanyak 24 orang. Untuk persentase usia 31-40 tahun sebesar $21 \%$ atau sebanyak 8 orang. Untuk persentase usia $>40$ sebesar $16 \%$ atau sebanyak 6 orang.

karakteristik responden berdasarkan masa kerja 0-5 Tahun sebesar $82 \%$ atau sebanyak 31 orang. Untuk masa kerja 5-15 tahun sebesar $18 \%$ atau sebanyak 7 orang.

\section{Analisis Data}

Penelitian uji reliabilitas dilakukan dengan cara one shot, yaitu nilai cronbac's alpha variabel $>0,6$ maka indikator yang digunakan oleh variabel tersebut reliabel, sedangkan nilai cronbac's alpha suatu variabel $<0,60$ maka indikator yang digunakan oleh variabel tersebut tidak reliabel.

Berdasarkan hasil perhitungan diperoleh nilai Alpha-Cronboch masing-masing butir pertanyaan telah memenuhi syrat reliabilitas, yaitu nilai Alpha-Cronboch masing-masing butir pertanyaan tersebut telah melebihi syarat minimal tingkat reliabilitas atau Alpha- Cronboch $>0,6$. Dengan demikian semua indikator yang digunakan dalam penelitian ini dinyatakan reliabel untuk mengukur variabel kompensasi finansial, pemberdayaan terhadap kinerja karyawan.

\section{Pengujian Hipotesis}

Dalam penelitian ini dilakukan pengujian hipotesis untuk mengetahui pengaruh kompensasi finansial dan pemberdayaan terhadap kinerja karyawan. Pengujian hipotesis pada penelitian ini meliputi koefisien determinasi (R2) dan uji t.

\section{a. Koefisien Korelasi $(\mathbf{R})$ dan Koefisien Determinasi $\left(\mathbf{R}^{2}\right)$}

Hasil uji Koefisien Korelasi (R) dapat disimpulkan bahwa didapat sebesar 0,833 atau 83,30\% sehingga menunjukkan bahwa bahwa variabel independen yakni Kompensasi Finansial (X1), Pemberdayaan $\left(\mathrm{X}_{2}\right)$ dan Kinerja Karyawan $(\mathrm{Y})$ sebagai variabel dependen terdapat hubungan yang sangat kuat. Hal ini ditunjukkan dari hasil perhitungan koefisien korelasi sebesar 0,833 atau 83,30\% berada di kriteria 0,8000 sampai dengan 1,000. 
Koefisien determinasi $\left(\mathrm{R}^{2}\right)$ didapat sebesar 0,695 atau $69,50 \%$ yang menunjukkan besarnya proporsi yang dapat dijelaskan oleh variabel kompensasi finansial, pemberdayaan terhadap kinerja karyawan, sedangkan sisanya sebesar 30,50\% kinerja karyawan dipengaruhi oleh variabel lain yang tidak dijelaskan dalam penelitian ini.

\section{b. Uji t}

Berdasarkan dari table analisis dapat disimpulkan bahwa :

$\mathrm{Y}=9,763+0,875 \mathrm{X}_{1}+0,194 \mathrm{X}_{2}$

Dilihat dari rumus persamaan tersebut, maka dapat penjelasan sebagai berikut :

a) Konstanta bernilai 9,763 hal ini menunjukkan jika ada variabel bebas (kompensasi finansial, pemberdayaan), maka kinerja karyawan akan meningkat sebesar 9,763.

b) Jika variabel kompensasi finansial (X1) berubah mengalami peningkatan sebesar satu satuan maka kinerja (Y) akan berubah dengan mengalami peningkatan sebesar 0,875 dengan anggapan bahwa faktorfaktor lain bernilai tetap.

c) Jika variabel pemberdayaan (X2) berubah mengalami peningkatan sebesar satu satuan maka kinerja (Y) akan berubah dengan mengalami peningkatan sebesar 0,194 dengan anggapan bahwa faktor-faktor lain bernilai tetap.

Dari penjelasan diatas, dapat disimpulkan bahwa yang paling mempengaruhi kinerja (Y) karyawan PT. Samudra Maju Perkasa adalah variabel kompensasi finansial (X1) dengan pengaruh sebesar 0,875 . Selanjutnya di posisi kedua adalah variabel pemberdayaan (X2) dengan pengaruh sebesar 0,194 dalam mempengaruhi kinerja (Y) karyawan PT. Samudra Maju Perkasa.

Berdasarkan uraian diatas dapat juga disimpulkan bahwa :

1) Variabel Kompensasi Finansial (X1) memiliki thitung sebesar 7,137 dengan signifikansi 0,000. Sedangkan ttabel diperoleh sebesar 2,030 dengan tingkat signifikansi 5\% atau 0,05. Hasil perhitungan uji t di atas menunjukkan bahwa thitung $>$ ttabel $(7,137>2,030)$. Kemudian nilai probabilitas signifikansi sebesar $0,000<0,05$ yang berarti Ho ditolak dan Ha diterima. maka dapat diketahui bahwa secara parsial variabel kompensasi finansial berpengaruh positif dan signifikan terhadap kinerja karyawan. Dengan demikian (H1): "diduga, kompensasi finansial berpengaruh positif dan signifikan terhadap kinerja karyawan PT. Samudra Maju Perkasa Kota Samarinda," terbukti atau diterima.

2) Variabel Pemberdayaan (X2) memiliki thitung sebesar 2,550 dengan signifikansi 0,015. Sedangkan ttabel diperoleh sebesar 2,030 dengan tingkat signifikansi 5\% atau 0,05. Hasil perhitungan uji t di atas menunjukkan bahwa thitung $>$ ttabel $(2,550>2,030)$. Kemudian nilai probabilitas signifikansi sebesar $0,015<0,05$ yang berarti Ho ditolak dan Ha diterima. maka dapat diketahui bahwa secara parsial variabel pemberdayaan berpengaruh positif dan signifikan terhadap kinerja karyawan. Dengan demikian (H2): "diduga, pemberdayaan berpengaruh positif dan signifikan terhadap kinerja karyawan PT. Samudra Maju Perkasa," terbukti atau diterima.

\section{SIMPULAN}

1. Kompensasi Finansial berpengaruh positif dan signifikan terhadap Kinerja Karyawan PT. Samudara Maju Perkas Kota Samarinda.

2. Pemberdayaan berpengaruh positif dan signifikan terhadap Kinerja Karyawan PT. Samudara Maju Perkas Kota Samarinda. 


\section{DAFTAR PUSTAKA}

Clutterbuck, David. 2008. "The Power Of Empowerment (Terj)", Gramedia, Jakarta. Colquitt, Jason A., Jaffery A. LePine, dan Michael J. Wesson. 2011. "Organizational Behavior”, McGraw-Hill, New York.

Cook, Sarah and Steve Macaulay. 2006. "Perfect Empowerment, Pemberdayaan Yang Tepat", PT Elex Media Komputindo, Jakarta. 1997. "Perfect Empowerment” (ahli Bahasa: Paloepi Tyas R.) PT Elex Media Komputindo, Jakarta.

Dessler, Gary. 2000. "Human Resource Management”, Eight Edition, Prentice Hall, Inc, New Jersey.

Gibson, James L., John M. Ivancevich dan James H. Donnelly, Jr., dan Robert Konopaske. 2012. "Organizations", McGrew-Hill, New York.

Ghozali, Imam. 2013. “Aplikasi Analisis Multivariate Dengan Program SPSS”, BP Universitas Diponogoro, Semarang.

Hasibuan, Malayu, SP. 2012. "Manajemen Sumber Daya Manusia", edisi revisi, Penerbit: Bumi Aksara, Jakarta.

Ivancevich, John M., Robert Konopaske, dan Michael T. Mattesson. 2008. "Organizational Behavior and Management", McGraw-Hill, New York.

Iskandar. 2008. "Metodologi Penelitian Pendidikan dan Sosial (Kuantitatif dan Kualitatif)", Gaung Persada Press, Jakarta.

Kahn, S. 2007. "The Key Being a Leader Company Empowerment”. Journal For Quality and Participation, New Jersey.

Mangkunegara, A.A. Anwar Prabu. 2015. “Manajemen Sumber Daya Manusia Perusahaan”,PT Remaja Rosdakarya, Bandung.

Malthis, Robert, L. dan John H. Jackson, 2001. Human Resource Management (Manajemen Sumber Daya Manusia), Edisi Sepuluh, Terjemahan: Diana Angelica, Penerbit: Salemba Empat, Jakarta.

Mitchell Stewart, Aileen. 2008. "Empowering People,Pemberdayaan Sumber Daya Manusia”, Kanisius, Yogyakarta

Noe, Raymond A., John R. Hollenbeck, Barry Gerhart, and Patrick M. Wright. 2004. "Human Resource Management Gaining Competitive Advantage, 3rd Edition", McGraw-Hill.

Robbins, Stephen P. 2000. "Essensials Of Organizational Behavior”, Printice Hall International, Inc, New Jersey.

Sinambela, Lijan Poltak. 2016. "Manajemen Sumber Daya Manusia”, PT Bumi Aksara, Jakarta.

Sugiyono.2016. “Metode Penelitian Manajemen”, CV Alvabeta, Bandung.

Umar, Husein. 2008 "Desain Penelitian MSDM dan Perilaku Karyawan Paradigma Positivik dan Berbasis Pemecahan Masalah", PT Raja Grafindo Persada, Jakarta.

Widodo, Suparno Eko. 2015. "Manajemen Pengembangan Sumber daya Manusia”, Pustaka Pelajar, Yogyakarta.

Wibowo. 2014. “Manajemen Kinerja”, Edisi Keempat, PT RajaGrafindo Persada, Jakarta.

Copyright ${ }^{\odot}$ 2017, K I N E R J A

Print ISSN: 19073011 - Online ISSN: 2528-1127 